\title{
Auditor's Professional Skepticism: An Empirical Study At Public Accounting Firm in Central Java Province
}

\author{
Ardiani Ika Sulistyawati ${ }^{1}$ and Aprih Santoso ${ }^{2^{*}}$ \\ ${ }^{1,2}$ Economics Faculty, Semarang University, Semarang \\ Email Address: \\ ardiani@usm.ac.id, *aprihsantoso@usm.ac.id
}

\begin{abstract}
This study examines and analyzes the effect of experience, expertise, audit situation, ethics, and legal certainty on auditors' professional skepticism. The sample of this research is auditors who work at a public accounting firm in Central Java Province. Samples were taken using the non-probability sampling method, using the purposive sampling technique with 104 auditors as respondents. The analysis method used is PLS analysis. The research results show that experience and ethics affect the professional skepticism of auditors, while expertise, audit situation, and legal certainty do not affect the professional skepticism of auditors. The results of this study are expected to maintain the professional skepticism of auditors in evaluating critical audit evidence.
\end{abstract}

Keywords: experiences, expertise, audit, ethics, skepticism.

\begin{abstract}
Abstrak: Penelitian ini menguji dan menganalisis pengaruh pengalaman, keahlian, situasi audit, etika, dan kepastian hukum terhadap skeptisisme profesional auditor. Sampel penelitian ini auditor yang bekerja pada Kantor Akuntan Publik di Provinsi Jawa Tengah. Sampel diambil dengan menggunakan metode non probability sampling, dengan menggunakan teknik purposive sampling dengan responden sebanyak 104 auditor. Metode analisis yang digunakan analisis PLS. Hasil penelititan menunjukkan pengalaman dan etika berpengaruh terhadap skeptisisme profesional auditor, sedangkan keahlian, situasi audit, dan kepastian hukum tidak mempengaruhi skeptisisme profesional auditor. Hasil penelitian ini diharapkan dapat menjaga skeptisisme profesional auditor dalam mengevaluasi bukti audit kritis.
\end{abstract}

Kata Kunci: pengalaman, keahlian, audit, etika, skeptisisme.

\section{INTRODUCTION}

In auditing, the services provided by public accountants conduct audits (examinations) of the company's financial statements and provide opinions (ideas) on whether the company's financial statements have been fairly presented following Financial Accounting Standards established by the Indonesian Accountants Association (IA, 2001). The company's financial statements that have been audited by the Public Accounting Firm will be used by various interested parties (company leaders, shareholders, government, creditors, and employees) in making decisions. 
The audit of financial statements conducted by auditors is intended so that users of financial statements have the belief that the financial statements presented by company management are fair or free from material misstatement and are following the applicable Financial Accounting Standards, so they can be trusted as a basis for decision making. Therefore, in providing the right opinion or the accuracy of giving an opinion, the auditor must meet the criteria in the Public Accountant Professional Standards (PAPS) in force. In collecting such evidence, the auditor must always use the professional skepticism of the auditor to be able to use his professional skills carefully and thoroughly so that the objective of the auditor to obtain sufficient competent evidence and provide an adequate basis in formulating an opinion can be achieved properly (Winantyadi and Waluyo, 2014).

The Public Accountant Professional Standard defines the auditor's professional skepticism as an auditor's attitude that includes questioning thoughts and always conducting critical evaluations of audit evidence (IAI, 2001). These auditing standards require auditors to have professional skepticism in evaluating and collecting audit evidence, especially those related to assignments to detect fraud (Winantyadi and Waluyo, 2014). To carry out an audit engagement, an auditor is required to be skeptical of the evidence provided by his client to produce good audit quality. Auditor's professional skepticism is needed to minimize errors made by auditors when examining financial statements (Alfa and Indarto, 2013).

In the implementation of the practice of auditing services carried out by public accountants, some people still have doubts about the level of professional skepticism held by public accountant firm auditors, which in turn has an impact on public doubts about the provision of public accountant opinions. In Indonesia, there are sanctions imposed by Capital Market Supervisory Agency (Badan Pengawas Pasar Modal/Bapepam), including against Public Accounting Firm ZAF, namely sanctions for suspension of practice licenses for 6 months starting January 23, 2009, for violations of auditing standards, PAPS in conducting audits of PT. LLS for the fiscal year 2007. Sanctions for license suspension for 12 months starting December 10, 2008, against Public Accounting Firm TW for violations of Accounting Standard-PAPS in the audit of the PUPB employee welfare foundation for the period of 31 October 2006 - 31 July 2007. Cases of violations against PAPS in auditing the financial statements of PT. SR in 2005 and PT. HBP in 2004 resulted in the suspension of practice permit sanctions for 12 months from March 6, 2008, against KAP EL (Agoes, 2012).

(Winantyadi and Waluyo, 2014) which is based on Accounting and Auditing Releases (AAERs) from the Securities and Exchange Committee (SEC) found that the third-ranking cause of audit failure is the inadequate level of auditor's professional skepticism. Of the 40 audit cases that the SEC investigated, 24 (60 percent) occurred because the auditors did not apply an adequate level of professional skepticism to the audience. So the low level of Auditor's Professional Skepticism can lead to the failure to detect fraud. This failure, apart from being economically detrimental to the public accounting firm, also caused the loss of the reputation of the public accountant in the eyes of the public and the loss of creditor and investor belief in the capital market. (Winantyadi and Waluyo, 2014) states that auditors' professional skepticism has a relationship with other factors such as experience, expertise, audit situation, and ethics possessed by the auditors. 
The audit experience is demonstrated by the auditor's hours of experience in performing audit procedures related to providing an opinion on the audit report. The experience referred to here is the experience of the auditor in examining financial statements in terms of both the length of time and the number of assignments that have been performed. An auditor should first seek professional experience under the supervision of a more experienced senior auditor. (Winantyadi and Waluyo's, 2014) research shows that if auditors have high experience, the auditor's professional skepticism will also be high. The experience factor is one of the important elements in the audit tasks because it affects the level of professional skepticism of the auditors.

(Winantyadi and Waluyo, 2014) define expertise as the existence of knowledge about a certain environment, understanding of the problems that arise in that environment, and skills to solve these problems. (IAI, 2001), auditors can attain expertise through formal education and audit practice, besides that auditors must undergo sufficient technical training covering both technical and general education aspects. The first general standard regulates the requirements for the expertise of auditors in carrying out their profession. The auditor must have undergone sufficient technical education and training in accounting practice and auditing techniques. From the Enron case above, it can be concluded that the high level of expertise possessed will not necessarily guarantee the auditor will always succeed in exercising credibility as an auditor properly.

In carrying out their duties, the auditors are often faced with various situations. (Winantyadi and Waluyo, 2014), an example of an audit situation is related party transaction, close friendship between the auditor and the client, the client being audited is a person who has a strong power in a company who will influence the professional skepticism of the auditors in providing the right opinion. Irregularities are the condition where there is irregularity or fraud committed on purpose. This fraud can involve two things, namely the existence of pressure or encouragement in committing fraud or an opportunity to carry out the fraud.

The ability to be able to identify ethical and unethical behavior is very useful for all professions including auditors following the principles of professional ethics and code of ethics to support the auditor's performance. If an auditor has bad ethics, it will damage public belief in the auditor profession. If an auditor adheres to the code of ethics, he will be more skeptical in making a plan, he will always be careful because there is a suspicion that whether the evidence collected is sufficient or not (Alfa and Indarto, 2013).

\section{THEORETICAL REVIEW}

Cognitive Dissonance Theory. The theory of Cognitive Dissonance was developed by Leon Festinger in 1960. (Robbins and Judge, 2015) proposes that the case of the attitude following behavior illustrates the effect of cognitive dissonance, which is any mismatch that an individual feels between two or more attitudes or between behavior and attitudes. All forms of inconsistency are uncomfortable and that individuals will seek to reduce it. People do seek consistency between their attitudes and between behavior and attitudes.

(Robbins and Judge, 2015) argue that the desire to reduce dissonance depends on three factors, including the importance of the elements that create it and the degree of our belief influence. Individuals will be more motivated to reduce dissonance when the attitude is considered important or when they believe that the dissonance can be 
controlled. The third factor is the reward of dissonance; high rewards tend to lower the stress inherent in dissonance.

The development of dissonance will cause a person to experience psychological discomfort. This will motivate some one to reduce the dissonance by avoiding information or events that can increase dissonance (Noviyanti, 2008). This theory helps to predict the tendency of individuals to change attitudes and behavior to reduce dissonance that occurs, usually in the form of changing one or both of the cognitive elements involved or in the form of adding a third cognitive element in such a way that consonance is achieved again (Noviyanti, 2008).

\section{Logical Relationship Between Variables and Hypothesis Formulation}

The Relationship of Experience on Auditor's Professional Skepticism. (Winantyadi and Waluyo, 2014) suggest that if auditors have high experience, the auditor's professional skepticism will also be high. This research is in line with (Silalahi, 2013) which shows that experience has a positive effect on auditors' professional skepticism. The longer the experience of an auditor, the higher the auditor's professional skepticism.

An auditor should first seek professional experience under the supervision of a more experienced senior auditor. The way to view and respond to information obtained during the examination between experienced and inexperienced auditors will be different. The experience factor is one of the important elements in the audit tasks because it affects the level of professional skepticism of auditors (Winantyadi and Waluyo, 2014). (Drupadi and Sudana, 2016) stated that with experience, auditors will be able to distinguish relevant and irrelevant information. Reducing the influence of irrelevant information in the auditor's judgment will result in a more accurate audit judgment.

H1: Experience affects the professional skepticism of auditors.

The Relationship of Expertise on Auditor's Professional Skepticism. The higher the audit expertise possessed by an auditor, the more accurate the auditor's decisions will be (Drupadi and Sudana, 2016). Auditors can attain expertise through formal education and audit practice, besides, auditors must undergo sufficient technical training covering both technical and general education aspects. The first general standard regulates the expertise requirements of auditors in carrying out their profession. The auditor must have undergone sufficient technical education and training in accounting practices and auditing techniques (Winantyadi and Waluyo, 2014). An auditor who has high expertise will be able to face audit tasks, process relevant information, and analyze audit evidence so that it can support accurate decision making and information to determine the quality of the audit results and also the opinion that will be expressed by the auditor (Drupadi and Sudana, 2016).

H2: Expertise affects auditors' professional skepticism.

The Relationship of Audit Situation on Auditor's Professional Skepticism. In carrying out their duties, auditors are often faced with a variety of situations. (Winantyadi and Waluyo, 2014), the situation factor positively affects auditors' professional skepticism. Situation factors such as an audit situation that has a high risk (irregularities situation) 
affect the auditor to increase the auditor's professional skepticism. The results of this study are in line with the research results of (Winantyadi and Waluyo, 2014) which state that there is a positive and significant influence between the Audit Situation and the professional skepticism of auditors. (Silalahi, 2013) research results show that if the auditor faces a high-risk audit situation, the auditor's professional skepticism will also be high. Where in the implementation of the audit and audit finds high-risk audit situation, then in gathering audit evidence it is necessary to have higher skepticism because the audit is designed to provide adequate belief in the detection of material misstatements in the financial statements. Based on the description above, it can be concluded that the audit situation is a situation that occurs when the audit is carried out. With a variety of audit situations, the auditor must have a level of vigilance against possible frauds for the audit to be effective.

H3: The audit situation affects the professional skepticism of the auditor.

The Relationship of Ethics on the Auditor's Professional Skepticism. (Winantyadi and Waluyo, 2014) stated that there is a positive and significant influence between audit ethics and auditors' professional skepticism. These results are the same as the research conducted by (Silalahi, 2013) which shows a positive effect between ethics and auditors' professional skepticism. The higher the level of ethical awareness or unethical actions used in the decision-making, the higher the professional skepticism of the auditor. Accountants are constantly faced with ethical dilemmas that involve the choice among the values that are contrary to the ethical principles of auditors. So with the professional judgment of auditors, skepticism is very important in upholding ethical principles (Silalahi, 2013). Ethical awareness plays a key role in all areas of the accounting profession, including in training auditor's professional skepticism (Winantyadi and Waluyo, 2014).

Based on the above understanding, it can be concluded that ethics is a way of acting from an auditor both in relationships with family, community, environment and with clients. Whether the action is taken following the rules or norms prevailing in society and whether it is under the auditor's professional code of ethics. Thus also with the profession of auditors, in carrying out their duties, they must apply the ethical attitude of auditors in implementing audit practices.

H4: Ethics affects the professional skepticism of auditors.

The Relationship of Legal Certainty on Auditor's Professional Skepticism. In Indonesia, a new regulation has emerged which regulates the public accounting profession, namely Law no. 5 of 2011. The real impact of the implementation of this Law is that public accountants are starting to be careful in carrying out their assignments and giving their opinions. This is due to the existence of criminal regulations for criminals listed in the Public Accountants Law. Thus the public accountants will be motivated to act more professionally and independently in carrying out their profession. On the other hand, the application of criminal sanctions in the law on public accounting is also intended to protect the public accountant profession, namely by providing legal certainty to the existence of clear formulations regarding the types included in the category of criminal acts committed by public accountants. At least the existence of this Law can minimize 
fake public accountants from being able to operate in Indonesian territory freely (Jauharia, 2012).

(Ansari and Hendarjatno, 2014) stated that the implementation of the Public Accountants Law had a positive impact on the professionalism of auditors, in other words, auditors were more careful in carrying out their audit duties. In contrast to (Ansari and Hendarjatno, 2014), the Public Accountants Law does not affect, does not strengthen, or weaken the relationship between competence and independence and audit quality. Based on the explanation above, it can be concluded that skepticism has a close relationship to make law as behavior guidance in every law action to guarantee the functioning of legal norms implemented in social and state life.

H5: Legal certainty affects the professional skepticism of auditors.

\section{Theoretical Framework of Idea}

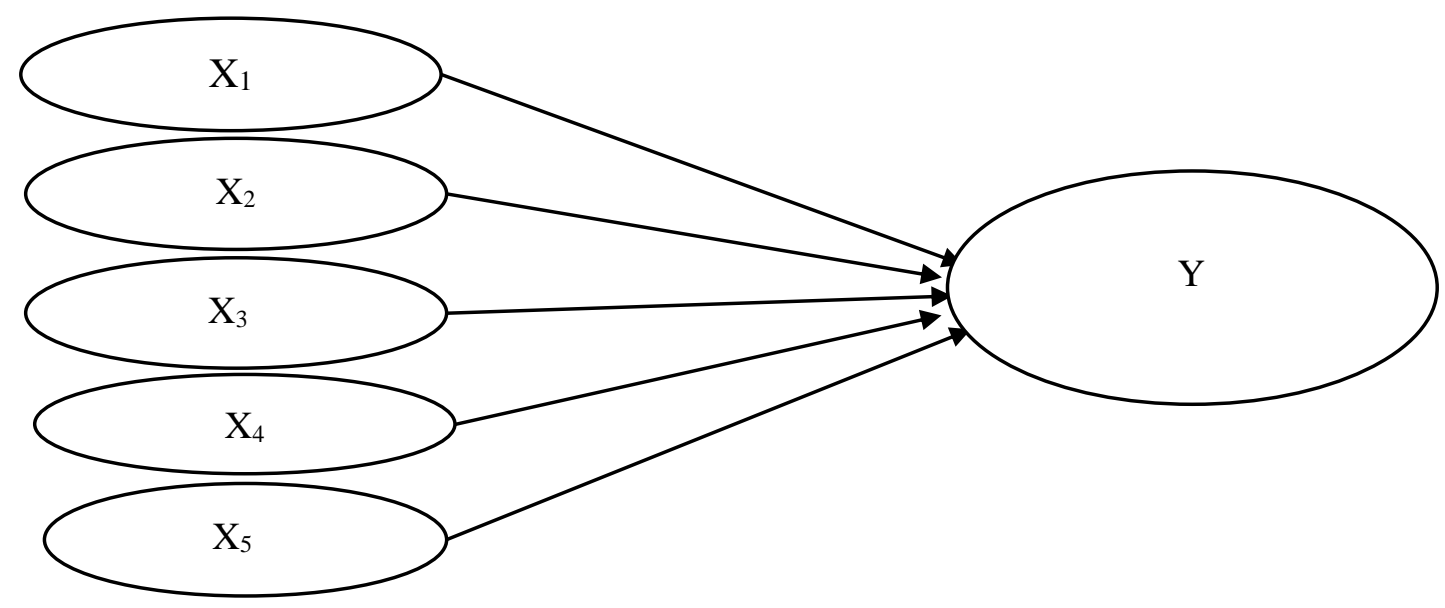

Figure 1. Reaserch Model

\section{METHODS}

The independent variables in this study are experience, expertise, audit situation, ethics and legal certainty. The dependent variable in this study is audit quality. Respondents' answers were scored using a 5 (five) point Likert scale, ranging from strongly disagreeing to agreeing. The study population was the auditors of the Public Accounting Firm in Central Java Province. The method used was saturated sampling or census of 104 respondents. The data collection technique used was the inquiry or questionnaire method. The questions relate to the demographic data of respondents and responses regarding the Professional Skepticism of the Auditor, Experience, Expertise, Audit Situation, Ethics and Legal Certainty of the auditors who work at a public accounting firm in Central Java Province.

Method of Analysis. PLS as a prediction model does not assume a normal distribution to estimate parameters and predict the causality relationship. Based on this, the parametric 
technique for parameter significance test is not needed and the evaluation model for prediction is non-parametric. The reason for using non-parametric techniques is due to the ordinal scores of respondents' answers on the Likert scale. The PLS model evaluation is carried out by evaluating the outer model and inner model. Outer model is a measurement model to assess the validity and reliability of the model. Through the algorithm iteration process, the measurement parameters of the model (convergent validity, discriminant validity, composite reliability and Cronbach's alpha) are obtained which are the requirements of the PLS analysis, including the R2 value as the parameter of the prediction model accuracy. The next step is to evaluate the structural model or inner model, which is a structural model to predict the causality relationship between latent variables. The structural model or inner model is processed through bootstrapping, in order to obtain a T-statistic test parameter to predict the causality relationship. The equation model is:

$Y=\beta_{1} X_{1}+\beta_{2} X_{2}+\beta_{3} X_{3}+\beta_{4} X_{4}+\beta_{5} X_{5}+\varepsilon$

Information

$\mathrm{Y}=$ Professional Skepticism of the Auditor

$\mathrm{X}_{1} \quad=$ Experience

$\mathrm{X}_{2} \quad=$ Expertise

$\mathrm{X}_{3}=$ Audit Situation

$\mathrm{X}_{4} \quad=$ Ethics

$\mathrm{X}_{5} \quad=$ Legal Certainty

$\beta_{1}-\beta_{5}=$ regression coefficient

$\varepsilon=$ Error

\section{RESULTS}

Convergent validity test in PLS with reflective indicators is assessed based on the loading factor (free of item scores / component scores with construct scores) indicators that measure these constructs. The rule of thumb used for convergent validity is outer loading > 0.7, Communality> 0.5 and average variance extracted (AVE) $>0.5$ (Chin \& Todd, 1995). In the analysis of the measurement model consists of 3 stages, or until the final stage is obtained, the loading factor value is more than 0.7. The results of the evaluation of the PLS measurement model can be seen in the following table :

Table 1. Outer Loading Confirmatory Test Phase 1

\begin{tabular}{lllllll}
\hline & X1 & X2 & X3 & X4 & X5 & Y \\
\hline X1.1 & 0.804 & & & & \\
X1.2 & 0.703 & & & & \\
X1.3 & 0.732 & & & & \\
X1.4 & 0.769 & & & & \\
X1.5 & 0.607 & & & & \\
X1.6 & 0.716 & & & & \\
X2.1 & & 0.537 & & &
\end{tabular}




\begin{tabular}{|c|c|c|c|c|c|}
\hline $\mathrm{X} 2.2$ & 0.678 & & & & \\
\hline $\mathrm{X} 2.3$ & 0.536 & & & & \\
\hline X2.4 & 0.742 & & & & \\
\hline $\mathrm{X} 2.5$ & 0.699 & & & & \\
\hline $\mathrm{X} 2.6$ & 0.773 & & & & \\
\hline $\mathrm{X} 2.7$ & 0.809 & & & & \\
\hline X3.1 & & 0.692 & & & \\
\hline $\mathrm{X} 3.2$ & & 0.750 & & & \\
\hline X3.3 & & 0.752 & & & \\
\hline X3.4 & & 0.778 & & & \\
\hline X3.5 & & 0.463 & & & \\
\hline $\mathrm{X} 4.1$ & & & 0.858 & & \\
\hline $\mathrm{X} 4.2$ & & & 0.756 & & \\
\hline $\mathrm{X} 4.3$ & & & 0.787 & & \\
\hline $\mathrm{X} 4.4$ & & & 0.774 & & \\
\hline X5.1 & & & & 0.570 & \\
\hline X5.2 & & & & 0.715 & \\
\hline X5.3 & & & & 0.780 & \\
\hline X5.4 & & & & 0.794 & \\
\hline X5.5 & & & & 0.695 & \\
\hline Y1.1 & & & & & 0.798 \\
\hline Y1.2 & & & & & 0.765 \\
\hline Y1.3 & & & & & 0.748 \\
\hline Y1.4 & & & & & 0.717 \\
\hline Y1.5 & & & & & 0.578 \\
\hline
\end{tabular}

Based on the table above, it is known that there are still indicators whose value is below 0.7 , therefore the analysis is continued to stage 2 .

Table 2. Outer Loading Confirmatory Test Stage 2

\begin{tabular}{lllllll}
\hline & X1 & X2 & X3 & X4 & X5 & Y \\
\hline X1.1 & 0.802 & & & & \\
X1.2 & 0.725 & & & & \\
X1.3 & 0.772 & & & & \\
X1.4 & 0.776 & & & & \\
X1.6 & 0.676 & & & & \\
X2.4 & & 0.799 & & & \\
X2.6 & & 0.833 & & & \\
X2.7 & & 0.870 & & & \\
X3.1 & & & 0.697 & & \\
X3.2 & & & 0.771 & & \\
X3.3 & & & 0.762 & &
\end{tabular}




\begin{tabular}{lllll} 
X3.4 & 0.775 & & & \\
$X 4.1$ & & 0.859 & & \\
$X 4.2$ & 0.748 & & \\
$X 4.3$ & 0.791 & & \\
$X 4.4$ & 0.776 & & \\
$X 5.2$ & & 0.734 & \\
X5.3 & & 0.851 & \\
X5.4 & & 0.857 & \\
Y1.1 & & & 0.790 \\
Y1.2 & & & 0.761 \\
Y1.3 & & & 0.767 \\
Y1.4 & & & 0.745 \\
\hline
\end{tabular}

In stage 2, an indicator whose value is still below 0.7 is obtained, namely X1.6 and X3.1, therefore the analysis is continued to stage 3 .

Table 3. Outer Loading Confirmatory Test Stage 3

\begin{tabular}{|c|c|c|c|c|c|c|}
\hline & $\mathrm{X} 1$ & $\mathrm{X} 2$ & $\mathbf{X 3}$ & $\mathrm{X} 4$ & X5 & $\mathbf{Y}$ \\
\hline $\mathrm{X} 1.1$ & 0.811 & & & & & \\
\hline $\mathrm{X} 1.2$ & 0.757 & & & & & \\
\hline $\mathrm{X} 1.3$ & 0.818 & & & & & \\
\hline X1.4 & 0.754 & & & & & \\
\hline $\mathrm{X} 2.4$ & & 0.800 & & & & \\
\hline X2.6 & & 0.833 & & & & \\
\hline $\mathrm{X} 2.7$ & & 0.869 & & & & \\
\hline X3.2 & & & 0.762 & & & \\
\hline X3.3 & & & 0.793 & & & \\
\hline X3.4 & & & 0.802 & & & \\
\hline $\mathrm{X} 4.1$ & & & & 0.859 & & \\
\hline $\mathrm{X} 4.2$ & & & & 0.749 & & \\
\hline $\mathrm{X} 4.3$ & & & & 0.791 & & \\
\hline $\mathrm{X} 4.4$ & & & & 0.776 & & \\
\hline X5.2 & & & & & 0.735 & \\
\hline X5.3 & & & & & 0.851 & \\
\hline X5.4 & & & & & 0.857 & \\
\hline Y1.1 & & & & & & 0.788 \\
\hline Y1.2 & & & & & & 0.756 \\
\hline Y1.3 & & & & & & 0.769 \\
\hline Y1.4 & & & & & & 0.751 \\
\hline
\end{tabular}


In stage 3 , all indicators are obtained whose values are more than 0.7 , so that the evaluation is continued to the evaluation stage of the structural model. Following are the results of the analysis of the Average variance extracted (AVE) value.

Table 4. AVE Value

\begin{tabular}{lc}
\hline & Average Variance Extracted (AVE) \\
\hline $\mathrm{X} 1$ & 0.617 \\
$\mathrm{X} 2$ & 0.697 \\
$\mathrm{X} 3$ & 0.618 \\
$\mathrm{X} 4$ & 0.632 \\
$\mathrm{X} 5$ & 0.666 \\
$\mathrm{Y}$ & 0.587 \\
\hline
\end{tabular}

Based on the table above, it is found that all variables are greater than 0.5 indicating that after going through three stages, all items in each variable are declared valid and can be used.

Another method used to assess discriminant validity is to compare the AVE roots for each construct with other constructs in the model. A good discriminant model, if the AVE root for each larger construct, knows between the construct and the other constructs in the (Chin, 1995).

Table 5. Discriminant Validity

\begin{tabular}{lllllll}
\hline & X1 & X2 & X3 & X4 & X5 & Y \\
\hline X1 & 0.786 & & & & & \\
X2 & 0.621 & 0.835 & & & & \\
X3 & 0.582 & 0.643 & 0.786 & & & \\
X4 & 0.511 & 0.493 & 0.514 & 0.795 & & \\
X5 & 0.543 & 0.443 & 0.558 & 0.574 & 0.816 & \\
Y & 0.725 & 0.541 & 0.545 & 0.613 & 0.568 & 0.766 \\
\hline
\end{tabular}

The results above show that the discriminant value (thick number) is more than the value of the coefficient of the relationship between constructs, so it can be said that the model has good discriminant validity.

Reliability analysis. In addition to the validity test, PLS also conducts reliability tests to measure the consistency of internal measuring instruments. Reliability shows the accuracy, accuracy and precision of a measuring instrument in making measurements (Hartone 2008a). Reliability test in PLS can use two methods, namely Cronbach's alpha and Composite reliability. Alpha Cronbach measures the lower limit of the reliability value of a construct, while the reliability of the composite measures the true value of the reliability of a construct (Chin, 1995). However, composite reliability is better in estimating the internal consistency of a construct (Chin \& Todd, 1995). The rule of thumb value of alpha or Composite reliability must be greater than 0.7 although a value of 0.6 is still acceptable (Hair et al, 2014). But in fact, the internal consistency test is not absolute 
to do that construct validity has been fulfilled, because a valid construct is a reliable construct, on the other hand, a reliable construct is not necessarily valid (Cooper and Scindler, 2006).

Table 6. Reliability test

\begin{tabular}{lccc}
\hline & Cronbach's Alpha & rho_A & Composite Reliability \\
\hline X1 & 0.795 & 0.803 & 0.866 \\
X2 & 0.788 & 0.828 & 0.873 \\
X3 & 0.698 & 0.709 & 0.829 \\
X4 & 0.805 & 0.806 & 0.872 \\
X5 & 0.753 & 0.786 & 0.856 \\
Y & 0.765 & 0.766 & 0.850 \\
\hline
\end{tabular}

The reliability test results found that the alpha value is more than 0.7 except for the $\mathrm{X} 3$ construct, but when viewed from the Composite Reliability value all latent constructs are more than required.

Structural Model (Hypothesis Test). Structural models in PLS are evaluated using R for dependent constructs, path coefficient values or t-values for each path to test the significance between constructs in the structural model. The value used to measure the degree of variation in the change in the independent variable on the dependent variable. The higher the $\mathrm{R}$ value, the better the prediction of the proposed research model. For example, if the $\mathrm{R}$ value is 0.7 , it means that the change in the dependent variable that can be mentioned by the independent variable is 70 percent, while the rest is by other variables outside the proposed model. However, the parameters that are considered absolute in measuring the accuracy of the prediction model are because the theoretical basis of the relationship is the most important parameter to explain the causality relationship.

Table 7. $\mathrm{R}^{2}$ Determination Coefficient Test Results

\begin{tabular}{lll}
\hline & R Square & R Square Adjusted \\
\hline $\mathrm{Y}$ & 0.617 & 0.598 \\
\hline
\end{tabular}

The results show that $59.8 \%$ of the $\mathrm{Y}$ value can be explained by $\mathrm{X} 1, \mathrm{X} 2, \mathrm{X} 3, \mathrm{X} 4$, $\mathrm{X} 5$, while the remaining $40.2 \%$ is explained by other factors not examined in this analysis.

The path coefficient value or inner model shows the level of significance in testing the hypothesis. The path coefficient score or inner model, which is indicated by the Tstatistic value, must be above 1.96 . 
Table 8. Path Coefficients

\begin{tabular}{llllll}
\hline & $\begin{array}{l}\text { Original } \\
\text { Sample (O) }\end{array}$ & $\begin{array}{l}\text { Sample } \\
\text { Mean }(\mathbf{M})\end{array}$ & $\begin{array}{l}\text { Standard Deviation } \\
(\text { STDEV) }\end{array}$ & $\begin{array}{l}\text { T Statistics } \\
(\mid \mathbf{O} / \text { STDEV })\end{array}$ & $\begin{array}{l}\text { P } \\
\text { Values }\end{array}$ \\
\hline X1 -> Y & 0.481 & 0.477 & 0.104 & 4.626 & 0.000 \\
X2 -> Y & 0.034 & 0.035 & 0.103 & 0.333 & 0.739 \\
X3 -> Y & 0.043 & 0.050 & 0.109 & 0.399 & 0.690 \\
X4 -> Y & 0.259 & 0.254 & 0.072 & 3.616 & 0.000 \\
X5 -> Y & 0.119 & 0.125 & 0.088 & 1.351 & 0.177 \\
\hline
\end{tabular}

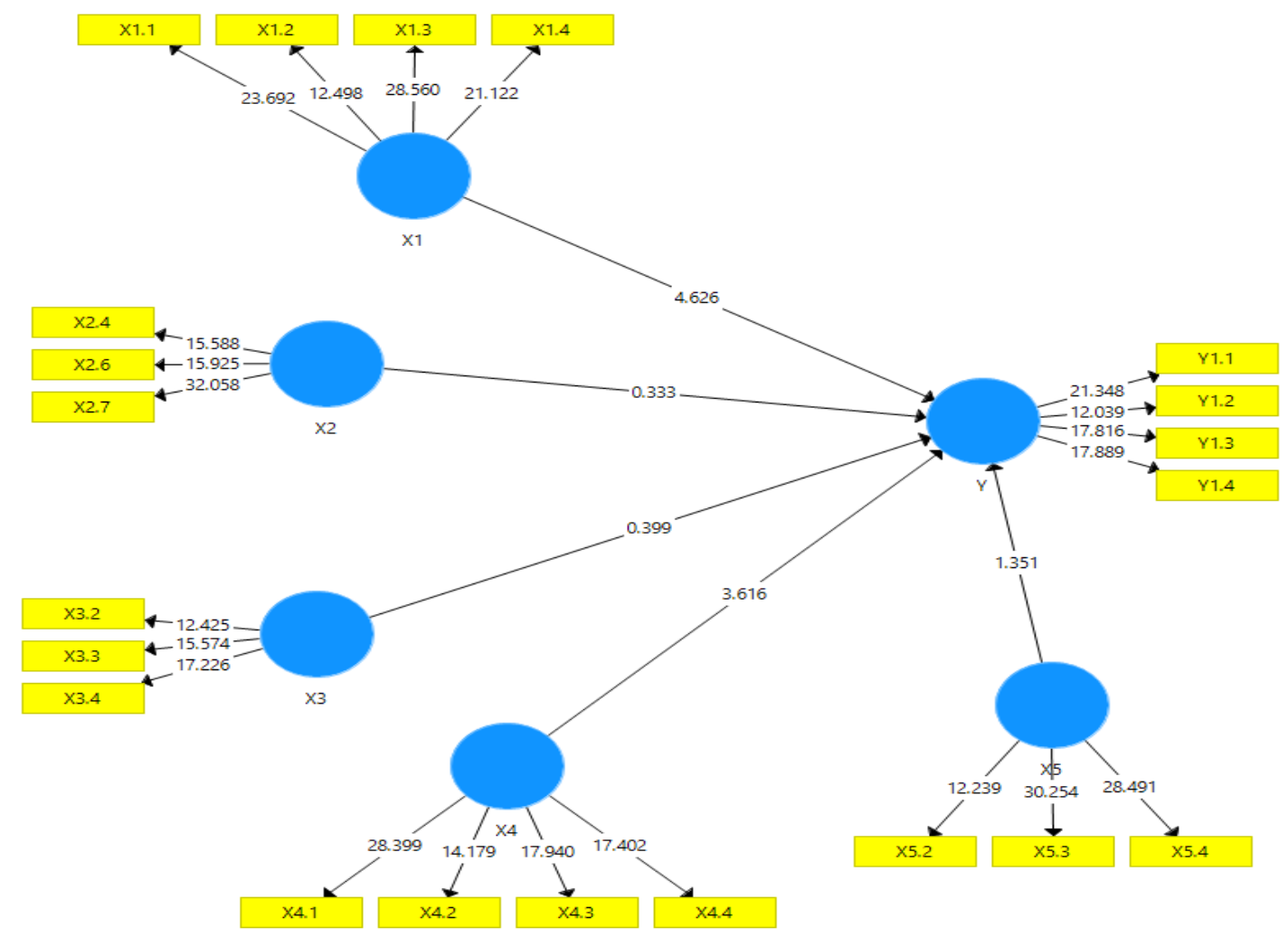

Figure 2. Path Coefficient between Variables

\section{DISCUSSION}

Experience Against Auditor's Professional Skepticism. Hypothesis 1 testing proves that experience affects the auditors' professional skepticism, so that audit experience can increase the auditors' professional skepticism. This shows that auditors who work at public accounting firm in Central Java, in carrying out their audit duties, always pay attention to the professional skepticism of the auditors they have. Audit experience makes an auditor more reliable in evaluating audit evidence and ultimately results in work quality and better accuracy of opinion so that this experience has an influence on the auditor in making decisions. In the validity test table, it can be seen that the X1.1 indicator has the 
highest correlation value, namely 0.804 , which indicates that the longer you become an auditor, the more you understand how to deal with the entity or object of examination in obtaining the required data and information. This condition shows that the longer the audit experience of an auditor, the higher the professional skepticism of the auditor, including the attitude that always questions and always performs a critical evaluation of audit evidence.

Accounting Standard 200, paragraph 13 (k), defines professional judgment: "the application of relevant training, knowledge, and experience, in the context of auditing, accounting, and ethical standards, in making informed decisions about the appropriate course of action in the circumstances of the audit engagement. Auditors must be proficient and thorough in carrying out audit tasks, auditors who work in public accounting firms in Central Java in carrying out audit duties must always pay attention to their professional skepticism. It can be explained that auditors have undergone formal education in the fields of auditing and accounting, have considerable practical experience in the field of work being carried out, then have undergone or had a continuing profession, and have technical qualifications and experience in auditing. The results of this study support (Winantyadi and Waluyo, 2014), (Silalahi, 2013) which state that the audit experience affects the professional skepticism of auditors.

Expertise Against Auditor's Professional Skepticism. Hypothesis 2 testing proves that expertise does not affect auditors' professional skepticism. The high expertise of an auditor can increase the auditor's professional skepticism. However, the results of this study indicate the low level of expertise possessed by auditors. Audit expertise includes all auditors' knowledge of the world of auditing itself, the benchmarks are the level of educational certification and the level of formal undergraduate education. Auditors who have a high level of knowledge will behave appropriately in accordance with the perceptions and expectations of others and the environment in which the auditors work. Thus, auditors can use skepticism in conducting audits. Adequate expertise will increase the professional skepticism of the auditors and will affect the accuracy of giving the auditor's opinion (Suraida, 2005).

In the validity test table, it can be seen that the $\mathrm{X} 2$. indicator has the highest correlation value, which is 0.809 which shows that as an auditor he feels that he can carry out audits in various situations, to provide the right audit opinion. This means that auditors who are faced with a variety of situations are expected to always use their expertise in each assignment and always apply the auditor's professional skepticism in auditing a company's financial statements to provide the right opinion. This result supports the research of (Sutrisno and Fajarwati, 2016) which states that expertise does not affect auditors' professional skepticism. However, the results of this study are different from those of (Winantyadi and Waluyo, 2014) which state that expertise affects the professional skepticism of auditors.

The Audit Situation Against the Auditor's Professional Skepticism. The testing results of hypothesis 3 indicate that the audit situation does not affect the professional skepticism of auditors. Auditor's professional skepticism is influenced by the audit situation because the various kinds of audit situations faced by the auditor will affect the level of 
professional skepticism and will affect the auditor's opinion. If the auditors face an audit situation with high risks, the auditor's professional skepticism will also be high.

In the validity test table, it can be seen that the X3.4 indicator has the highest correlation value, which is 0.778 which indicates that the greater the risk contained in the audit situation will affect the auditor in developing his professional skepticism. This means that in carrying out audit tasks, auditors are often faced with various kinds of situations caused by fraud or mistakes where the auditors have not fully applied skepticism because most respondents in this study are junior auditors with an average education of Bachelor Degree (S1) so that the attitude of more critical in encountering various situations is still lacking when compared to senior auditors. This result is not in line with (Winantyadi and Waluyo, 2014); (Silalahi, 2013) where the results of the study explain that the audit situation has a significant effect on the auditors' professional skepticism.

Ethics Against Auditor's Professional Skepticism. Hypothesis 4 testing proves that ethics affects the professional skepticism of auditors. In accordance with the principles of professional ethics in the IAI code of ethics which include aspects of trust, accuracy, honesty, and reliability, it is evidence that professional skepticism as an auditor is very important to fulfill the principles of (1) Professional responsibility, (2) Public interest, (3) Integrity, (4) Objectivity, (5) Professional competence and prudence, (6) Confidentiality, (7) Professional behavior, (8) Technical standards.

In the validity test table, it can be seen that the $\mathrm{X} 4.1$ indicator has the highest correlation value, which is equal to 0.858 , which indicates that in carrying out its duties, auditors maintain the good name of the profession by upholding professional ethics. This means that the auditors in carrying out their duties are based on professionalism regardless of the client's background so that the auditors always use independence so that they are not influenced by clients with various backgrounds. The higher the level of ethical awareness or unethical actions used in decision making, the higher the professional skepticism of the auditors. Accountants are constantly faced with ethical dilemmas that involve the choices between values that are contrary to the ethical principles of auditors. So, with the professional judgment of the auditor, skepticism is very important in upholding ethical principles. Auditor's professional skepticism is influenced by the characteristics of personal behavior (attitudes and ethical values) and the level of competence (knowledge) of the individuals conducting the audit. So, auditors must apply a code of ethics in every audit engagement to increase the auditor's skepticism. These results support (Winantyadi and Waluyo, 2014), (Silalahi, 2013); (Alfa and Indarto, 2013) which state that ethics affects the professional skepticism of auditors.

Legal Certainty Against Auditor's Professional Skepticism. Hypothesis 5 testing shows that legal certainty does not affect auditors' professional skepticism. This is due to a lack of understanding of Law no. 5 of 2011 concerning Public Accountants, so the laws and regulations do not affect the skepticism of an auditor. Article 6 in Law no. 5 of 2011 states that auditors must be experienced in providing audit service practices.

Accounting Standard 250 requires the auditor to determine whether he has a responsibility to report any identified or suspected non-compliance with law or regulation to parties outside the entity. In dissonance theory, humans like harmony, therefore humans 
will tend to take attitudes that are not contradictory to one another and avoid taking actions that are not following their attitudes. However, in the results of this study auditors are often forced to perform behaviors that are not following the attitudes and law regulations.

In table 4:14, it can be seen that the X5.4 indicator has the highest correlation value, which is 0.794 , which indicates that auditors always follow the developments related to the auditor profession and the applicable legal rules. This means that an auditor must always follow the applicable rules according to his profession and apply the principles of the auditor's code of ethics so that in providing an audit opinion, the auditor always uses his skepticism based on the prevailing laws and regulations.

The results of this study are not in line with (Jauharia, 2012) which shows that the application of the Public Accountants Law has a positive impact on auditor's professionalism, in other words, auditors are more careful in carrying out their audit duties.

\section{CONCLUSION}

Experience and ethics affect the professional skepticism of auditors, but expertise, audit situation, and legal certainty do not partially affect auditors' professional skepticism in the Public Accounting Firm in Central Java. The variables of experience, expertise, audit situation, ethics, and legal certainty together influence the professional skepticism of auditors.

The sample in this study is limited, due to the distribution of questionnaires carried out to respondents in the first quarter, namely February - March, which is the work schedule for auditors as a profession that audits the quarterly financial statements of the clients' companies. The data collected in this study used the closed questionnaire method, which allows dishonesty in answering questions and auditors cannot convey their opinions outside of the questions in the questionnaire.

Future research should not be carried out during the busy period of auditors at the Public Accounting Firm so that the data obtained can be optimal because many auditors are willing to fill out questionnaires. Further research can expand the research area so that more samples can be obtained. It should not only use the questionnaire method but also add an interview method to strengthen the answers in the questionnaire so that there is no difference in perceptions in interpreting the questions in the questionnaire.

\section{REFERENCE}

Agoes, S. (2012). Auditing Petunjuk Praktis Pemeriksaan Akuntansi oleh Akuntan Publik. Jakarta : Salemba Empat.

Alfa, R.D.L.C. dan Indarto, S.L. (2013). Faktor-Faktor Yang Mempengaruhi Skeptisisme Profesional Auditor Dalam Penugasan Audit. Jurnal Akuntansi Bisnis, 11(22), 115137.

DOI: https://doi.org/10.24167/jab.v11i22.418. http://journal.unika.ac.id/index.php/jab/article/view/418.

Ansari, R. dan Hendarjatno. (2014). Perbedaan Persepsi Resiko Audit, Materialitas Dan Kualitas Audit Sebelum Dan Sesudah Ketentuan Pidana UU NO. 5 Tahun 2011 Tentang AKuntan Publik (Studi Persepsi Pada Kantor Akuntan Publik Surabaya). 
Jurnal Ekonomi dan Bisnis Airlangga,24(2), 139-149. https://ejournal.unair.ac.id/JEBA/issue/view/496.

Chin, W. W. (1995). Partial Least Squares is to LISREL as Principal Components Analysis is to Common Factor Analysis. Technology Studies , 2, 315-319.

Chin, W.C. and Todd, P.A. (1995). On the Use, Usefulness and Ease of Use of Structural Equation Modelling in MIS Research: A Note of Caution. MIS Quarterly, 19, 237246.

Cooper, Donal R and Scindler, Pamela. (2006). Busines Research Methods. The MC Grow-Hill Lumpanies: Singapore.

Drupadi, M. J. dan Sudana, I.P, (2016). Pengaruh Keahlian Auditor, Tekanan Ketaatan Dan Independensi Terhadap Audit Judgment. E-Jurnal Akuntansi, 12(3), 623-655. https://ojs.unud.ac.id/index.php/Akuntansi/article/view/17839.

Hair, J., Hault, G., Ringle, C., and Sarstedt, M. (2014). A Primer On Partial Least Squares Structural Equations Modelling (PLS-SEM). Sage: United States of America.

Ikatan Akuntan Indonesia. (2001). Standar Profesional Akuntan Publik, Jakarta: Salemba Empat.

Jauharia, H. H. A. (2012). Optimalisasi Profesionalisme Auditor Melalui Undang-Undang No. 5 Tahun 2011. Dinamika Akuntansi Keuangan dan Perbankan, 1(2). 97-104. https://www.unisbank.ac.id/ojs/index.php/fe9/article/view/1589.

Noviyanti, Suzy. (2008). Skeptisme Profesional Auditor Dalam Mendeteksi Kecurangan. Jurnal Akuntansi dan Keuangan Indonesia, 5(1), 102-125.

Robbins, Stephen P. dan Judge, T.A. (2015). Perilaku Organisasi Edisi 16. Jakarta. Salemba Empat.

Silalahi, S. P. (2013). Pengaruh Etika, Kompetensi, Pengalaman Audit dan Situasi Audit Terhadap Skeptisme Profesional Auditor. Jurnal Ekonomi, 21 (03).

Suraida, Ida. (2005). Pengaruh Etika, Kompetensi, Pengalaman Audit dan Resiko Audit Terhadap Skeptisme Profesional Auditor dan Ketepatan Pemberian Opini Akuntan publik. Sosiohumaniora, 7(3). 186-202. DOI : https://doi.org/10.24198/sosiohumaniora.v7i3.5351.

http://jurnal.unpad.ac.id/sosiohumaniora/article/view/5351.

Sutrisno, S. dan Fajarwati, D. (2016). Pengaruh Pengalaman, Keahlian, Situasi Audit, Etika Dan Gender Terhadap Ketepatan Pemberian Opini Auditor Melalui Skeptisisme Profesional Auditor (Studi kasus pada KAP di Bekasi). Jurnal Riset $\begin{array}{lllll}\text { Akuntansi } \quad \& \quad \text { Komputerisasi } & \text { Akuntansi, 5(02). } & \text { 1-15. }\end{array}$ DOI: https://doi.org/10.33558/jrak.v5i2.1341. https://journal.unismabekasi.ac.id/index.php/jrak/article/view/1341

Winantyadi, N. dan Waluyo, I. (2014). Pengaruh Pengalaman, Keahlian, Situasi Audit, dan Etika terhadap Skeptisisme Profesional Auditor (Studi Kasus pada KAP di Provinsi Daerah Istimewa Yogyakarta). Nominal: Barometer Riset Akuntansi dan Manajemen, 3(1). 14-34. $\quad$ DOI: https://doi.org/10.21831/nominal.v3i1.2151. https://journal.uny.ac.id/index.php/nominal/article/view/2151. 